\title{
Effect of Pruning Severity and Irrigation Methods on Quality Production of Custard Apple
}

\author{
K. C. Anupama* and D. M. Panchbhai \\ Dr. Panjabrao Deshmukh Krishi Vidyapeeth, Akola, (MS), India \\ *Corresponding author
}

\begin{tabular}{|l|}
\hline Ke y w o r d s \\
Pruning, Irrigation, \\
$\begin{array}{l}\text { Fruit weight, Fruit } \\
\text { size, TSS, Acidity }\end{array}$ \\
\hline Article Info \\
$\begin{array}{l}\text { Accepted: } \\
16 \text { November } 2020 \\
\text { Available Online: } \\
10 \text { December } 2020\end{array}$ \\
\hline
\end{tabular}

\section{A B S T R A C T}

The experiment entitled "Effect of pruning severity and irrigation methods on quality production of custard apple" was carried out at Shivar block, Central Research Station, Dr. Panjabrao Deshmukh Krishi Vidyapeeth, Akola to study the effect of severity of pruning and methods of irrigation on quality production of custard apple. The experiment was laid out in Split Plot Design with three methods of irrigation viz., $\mathrm{I}_{1}$ - no irrigation, $\mathrm{I}_{2}$ - double furrow irrigation and $I_{3}$ - drip irrigation and severity of pruning are $P_{1}$ - no pruning, $P_{2}$ - light pruning, $\mathrm{P}_{3^{-}}$medium pruning and $\mathrm{P}_{4}$ - heavy pruning. The tree unit per treatment was two and it was replicated thrice with twelve treatment combinations. Better growth was shown by the heavy pruned $\left(\mathrm{P}_{4}\right)$ trees with respect to thickness of shoot. Light pruning $\left(\mathrm{P}_{2}\right)$ showed the highest number of shoots per branch. The fruit quality in respect of fruit weight, fruit size was found highest in heavy pruning $\left(\mathrm{P}_{4}\right)$ with drip irrigation $\left(\mathrm{I}_{3}\right)$ which was found at par with medium pruned trees. TSS and acidity was also found maximum in heavy pruned $\left(\mathrm{P}_{4}\right)$ trees but irrigation doesn't play significant role. The interaction between severity of pruning and methods of irrigation on fruit quality was found non-significant.

\section{Introduction}

Pruning is removal of any parts of tree, especially shoots, roots, buds or nipping of terminal parts. The main objective of pruning is to remove the non-productive parts and to divert the energy into those parts that are capable of bearing fruits (Singh, 2005). Pruning allows light to enter the interior parts of the tree and also control size of plant and regulate the fruit crop. Water is one of the most important factors limiting production of fruit crops, lack of water can lead to decline tree health, lower yield and poor quality of fruits. Frequent water stress may upset the nutrient status of plants. Water is used in photosynthesis to form sugar, as a solvent for biochemical reactions and for translocation of cell constituents.

Irrigation plays an important role in fruit cultivation and production. Average fruit size and weight are also increased in pruned trees as compared to those in un-pruned one. Although total fruit yield is slightly decreased, the quality of good size harvested fruit is increased with pruning. Regular annual pruning at bearing stage help to induce good healthy shoots which will provide maximum fruit bearing area and good quality 
fruits. Old bearing trees that have become low in vigour due to constant cropping should be pruned heavily, such trees respond better to heavy pruning because of their reduced vigour. In regions having limiting water, drip irrigation system help in judicious use of water. Contour terraces also help in efficient use of water. Drought conditions will produce a small fruit crop of poor quality fruit. In recent years the withdrawal of monsoon rains was found earlier ie. during September. Hence the fruit remains undersize and does not attain the full potential size and resulting low price in market due to small size fruits. Supplementary irrigation may play very important role for fruit development. Pruning and irrigation is important to custard apple as they help to get maximum yield and also to produce large and desirable fruit. Custard apple is a dry land crop they can thrive a wide range of soil and climatic conditions and they are not seriously affected by the pest and disease, so the production expenditure is less, climatic conditions of Maharashtra is one of the most suitable for custard apple production. So there is a scope for increasing area, production and productivity of custard apple.

\section{Materials and Methods}

The experiment entitled "Effect of pruning severity and irrigation methods on quality production of custard apple" was conducted at Shivar block, Central Research Station, Dr. Panjabrao Deshmukh Krishi Vidyapeeth, Akola. The experiment was conducted on 12 year old trees of custard apple cv. Balanagar spaced at $4 \times 4 \mathrm{~m}$. The present research programme is laid out in Split Plot Design consisting three methods of irrigation and four different severity of pruning replicated three times. Twelve year old custard apple plants were used for research programme. Two plants were selected under each treatment. Pruning was done with four pruning severity i.e. No pruning (control),
Light pruning: thickness of branch 3-5mm (Refill thickness), Medium pruning: thickness of branch 6-10mm (Pencil thickness) and Heavy pruning: thickness of branch $11-15 \mathrm{~mm}$ (Thumb thickness) with no irrigation (control), double furrow and drip irrigation.

\section{Results and Discussion}

The result obtained from the present investigation as well as relevant discussion have been summarized under following sub heads and given in table.

\section{Number of shoots emerged per branch}

The data from Table 1 showed that, effect of pruning severity on number of shoots emerged per branch was found to be significant. Significantly maximum number of shoots emerged (17.73) was found in control treatment $\left(\mathrm{P}_{1}\right)$ which were found at par with treatment light pruning (16.83) and followed by medium pruning (14.56). However, lowest number of shoots emerged per branch was recorded in heavy pruning treatment (13.32). These may be due to the fact that due to heavy pruning number of nodes will be decreased and so number of sprouts emerged will be less, hence number of shoots emerged decreases with increase in pruning. These results are in accordance with those reported by Dalkiliç et al., (2014) in peach and Dalal et al., (2004) in guava. The data presented in table 1 indicated that, the methods of irrigation showed non significant effect on number of shoots emerged per branch. The data presented in table 1 showed that, interaction effects due to severity of pruning and methods of irrigation was found non significant on number of shoots emerged.

\section{Average thickness of shoots (cm)}

The data from Table 1 showed that, effect of pruning severity on average thickness of 
shoots was found to be significant. Significantly maximum average thickness of shoots $(0.61 \mathrm{~cm})$ was produced in heavy pruning $\left(\mathrm{P}_{4}\right)$ which were found at par with treatment medium pruning $(0.59 \mathrm{~cm})$ and followed by light pruning $(0.55 \mathrm{~cm})$. However, lowest average thickness of shoots was recorded in unpruned $\left(\mathrm{P}_{1}\right)$ treatment $(0.54$ $\mathrm{cm})$. Hiwale and Raturi (1993) revealed that shoot diameter increased significantly with increasing severity of pruning. This may be due to the shift of metabolites from flowering sites to new vegetative growth sites influencing the increase in the shoot thickness and it is mainly due less number of shoots present in severely pruned branches than light pruned trees. It was revealed that diameter of shoots were significantly higher when pruned severely or moderately in ber (Raut and Diware, (2005). These results were also of present finding are in line with findings of Lian et al., (2019) in guava. The data presented in table 1 , indicated that the methods of irrigation showed non significant effect on average thickness of shoots. The data presented in table 1 showed that, interaction effects due to severity of pruning and methods of irrigation was found non significant on average thickness of shoots.

\section{According to number of fruits per tree}

\section{Grade 'A' (300g and above)}

The data from Table 1 showed that, effect of pruning severity on A grade quality fruits per tree was found to be significant. The medium pruning $\left(\mathrm{P}_{3}\right)$ produced significantly maximum A grade fruits per tree (11.81) which were found at par with heavy pruning (8.59) and light pruning (7.89). However, significantly lowest A grade fruits per tree was recorded in control treatment (5.54). The data from Table 1 showed that, methods of irrigation on $\mathrm{A}$ grade fruits per tree was found to be significant. Drip irrigation $\left(\mathrm{I}_{3}\right)$ produced significantly maximum A grade fruits per tree (10.93) was produced in which were found at par with double furrow irrigation (10.88) and lowest A grade fruits per tree was recorded in control treatment (3.56). The data presented in table 1 showed that, interaction effects due to severity of pruning and methods of irrigation was found non significant on A grade fruits per tree.

\section{Grade 'B' (200g-300g)}

The data from Table 1 showed that, effect of pruning severity on B grade fruits per tree was found to be significant. The light pruning $\left(\mathrm{P}_{2}\right)$ produced significantly maximum $\mathrm{B}$ grade fruits per tree (28.14) followed by medium pruning (20.23) and heavy pruning (18.96). However, lowest B grade fruits per tree was recorded in control treatment (14.83). The data presented in table 1 indicated that, the methods of irrigation showed non significant effect on B grade fruits per tree. The data presented in table 1 showed that, interaction effects due to severity of pruning and methods of irrigation was found non significant on B grade quality fruits per tree.

\section{Grade ' $C$ ' (150g-200g)}

The data from Table 1 showed that, effect of pruning severity on $\mathrm{C}$ grade fruits per tree was found to be significant. Significantly lowest $\mathrm{C}$ grade fruits per tree was recorded in heavy pruning (5.44) which were at par with medium pruning (8.05) followed by light pruning (17.43). While unpruned treatment $\left(\mathrm{P}_{1}\right)$ produced maximum $\mathrm{C}$ grade fruits per tree (20.96). The data presented in table 1 indicated that, the methods of irrigation showed non significant effect on $\mathrm{C}$ grade fruits /tree. The data presented in table 1 showed that, interaction effects due to severity of pruning and methods of irrigation was found non significant on $\mathrm{C}$ grade fruits per tree. 


\section{Grade 'D' (150g and below)}

The data from Table 1 showed that, effect of pruning severity on D grade fruits per tree was found to be significant. The heavy pruning produced significantly minimum D grade (2.38) fruits per tree which were at par with medium pruning (2.85) and followed by light pruning (10.77). However, highest D grade fruits per tree was recorded in unpruned $\left(\mathrm{P}_{1}\right)$ treatment (21.17). The data presented in table 1 indicated that, the methods of irrigation showed non significant effect on D grade fruits per tree. The data presented in table 1 showed that, interaction effects due to severity of pruning and methods of irrigation was found non significant on D grade fruits per tree.

\section{Fruit weight (g)}

The data from Table 2 showed that, effect of pruning severity on fruit weight (g) was found to be significant. Significantly maximum fruit weight $(238.49 \mathrm{~g})$ was produced in heavy pruning $\left(\mathrm{P}_{4}\right)$ which were found at par with medium pruning (233.27 g) followed by light pruning $(221.21 \mathrm{~g})$. However, lowest fruit weight was recorded in control treatment (191.52 g). This may be due to more nutrient supply to less number of fruits in case of severe pruning and also the increase in number and area of leaves increases the amount of photosynthates that cause a significant increase weight of fruit. The above results were also in agreement with the finding of Trevour and Steven (2009) in custard apple, Gupta and Gill (2014) in ber and Ahmad et al., (2006) in kinnow. The data from Table 2 showed that, methods of irrigation on fruit weight (g) was found to be significant. Significantly maximum fruit weight $(233.61 \mathrm{~g})$ was produced in drip irrigation $\left(\mathrm{I}_{3}\right)$ which was found at par with double furrow irrigation $(227.59 \mathrm{~g})$ and lowest fruit weight was recorded in control treatment $(202.17 \mathrm{~g})$. The increase in size and weight of fruits may be due to availability of optimum soil moisture content throughout entire fruit growing period because of frequent irrigation coupled with better nutrient supply. These result were in agreement with findings of Chen et al., (2018) in apple. The data presented in table 2 showed that, interaction effects due to severity of pruning and methods of irrigation was found non significant on fruit weight $(\mathrm{g})$.

\section{Fruit length (cm)}

The data from Table 2 showed that, effect of pruning severity on fruits length was found to be significant. Maximum fruit length (6.97 $\mathrm{cm})$ was produced in heavy pruning $\left(\mathrm{P}_{4}\right)$ which were found at par with medium pruning $(6.77 \mathrm{~cm})$ followed by light pruning $(6.40 \mathrm{~cm})$. Significantly minimum fruit length was recorded in control treatment $(5.44 \mathrm{~cm})$. This may be due to more nutrient supply to less number of fruits in case of severe pruning. Reducing fruit numbers at or soon after flowering has the effect of reducing competition for resources between fruit allowing individual fruit to develop greater cell numbers. The result of present finding are in line with Choudhary and Dhakare (2018) in custard apple, Bhagawati et al., (2015) in guava and Bhanu Pratap et al., (2009) in mango. The data presented in table 2 indicated that, the methods of irrigation showed non significant effect on fruit length. The data presented in table 2 showed that, interaction effects due to severity of pruning and methods of irrigation was found non significant on fruit length.

\section{Fruit breadth (cm)}

The data from Table 2 showed that, effect of pruning severity on fruit breadth was found to be significant. Significantly maximum fruit breadth $(7.27 \mathrm{~cm})$ was produced in heavy 
pruning $\left(\mathrm{P}_{4}\right)$ which were found at par with medium pruning $(7.10 \mathrm{~cm})$ followed by light pruning $(6.84 \mathrm{~cm})$. However, lowest fruit breadth was recorded in control treatment $(6.14 \mathrm{~cm})$. In severely pruned trees number of fruits is less as compared to unpruned trees so lower fruit numbers will give individual fruit a greater share of resources allowing cells to increase to the maximum size. The results of present findings are in agreement with finding of Singh and Dhaliwal (2004) and Bagchi et al., (2008) in guava. The data from Table 2 showed that, methods of irrigation on fruit breadth was found to be significant.
Significantly maximum fruit breadth $(7.10$ $\mathrm{cm})$ was recorded in drip irrigation $\left(\mathrm{I}_{3}\right)$ which was found at par with double furrow irrigation $(6.96 \mathrm{~cm})$ and lowest fruit breadth was recorded in control treatment $(6.45 \mathrm{~cm})$. The result of present finding are in line with Ghosh and Pal (2010) in mosambi, Ehret et al., (2012) in blue berry, Gurovich (2002) in grape and Meti (2013) in banana. The data presented in table 2 showed that, interaction effects due to severity of pruning and methods of irrigation was found non significant on fruit breadth.

Table.1 Effect of pruning severity and irrigation methods on no. shoots emerged/branch, average thickness of shoots, number of fruits per tree in different grades of custard apple

\begin{tabular}{|c|c|c|c|c|c|c|}
\hline \multirow[t]{2}{*}{$\begin{array}{l}\text { Treatment } \\
\text { details }\end{array}$} & \multirow[t]{2}{*}{$\begin{array}{c}\text { No. shoots } \\
\text { emerged/ } \\
\text { branch }\end{array}$} & \multirow[t]{2}{*}{$\begin{array}{l}\text { Average } \\
\text { thickness of } \\
\text { shoots }(\mathrm{cm})\end{array}$} & \multicolumn{4}{|c|}{$\begin{array}{l}\text { Number of fruits per tree } \\
\text { in different grades }\end{array}$} \\
\hline & & & A & B & $\mathrm{C}$ & D \\
\hline $\mathbf{I}_{1}$ & 16.86 & 0.56 & 3.56 & 21.12 & 11.87 & 9.18 \\
\hline $\mathbf{I}_{2}$ & 13.92 & 0.58 & 10.88 & 21.34 & 15.04 & 8.73 \\
\hline $\mathbf{I}_{3}$ & 16.06 & 0.58 & 10.93 & 19.16 & 11.99 & 9.96 \\
\hline S.E \pm & 1.14 & 0.01 & 0.65 & 0.76 & 0.84 & 0.69 \\
\hline CD at $5 \%$ & - & - & 2.54 & - & - & - \\
\hline $\mathbf{P}_{1}$ & 17.73 & 0.54 & 5.54 & 14.83 & 20.96 & 21.17 \\
\hline $\mathbf{P}_{2}$ & 16.83 & 0.55 & 7.89 & 28.14 & 17.43 & 10.77 \\
\hline $\mathbf{P}_{3}$ & 14.56 & 0.59 & 11.81 & 20.23 & 8.05 & 2.85 \\
\hline $\mathbf{P}_{4}$ & 13.32 & 0.61 & 8.59 & 18.96 & 5.44 & 2.38 \\
\hline $\mathrm{SE} \pm$ & 1.02 & 0.01 & 1.36 & 1.97 & 1.71 & 1.39 \\
\hline CD at $5 \%$ & 3.03 & 0.03 & 4.03 & 5.86 & 5.09 & 4.13 \\
\hline $\mathbf{I}_{1} \mathbf{P}_{1}$ & 18.03 & 0.56 & 1.87 & 19.05 & 20.06 & 18.18 \\
\hline $\mathbf{I}_{1} \mathbf{P}_{2}$ & 16.77 & 0.54 & 3.79 & 25.44 & 17.06 & 11.88 \\
\hline $\mathbf{I}_{1} \mathbf{P}_{3}$ & 16.17 & 0.57 & 4.19 & 20.45 & 8.30 & 2.90 \\
\hline $\mathbf{I}_{1} \mathbf{P}_{4}$ & 16.47 & 0.58 & 4.40 & 19.54 & 2.07 & 3.77 \\
\hline $\mathbf{I}_{2} \mathbf{P}_{1}$ & 13.73 & 0.55 & 7.61 & 11.44 & 22.68 & 19.94 \\
\hline $\mathbf{I}_{2} \mathbf{P}_{2}$ & 15.43 & 0.57 & 12.84 & 31.36 & 20.54 & 9.26 \\
\hline $\mathbf{I}_{2} \mathbf{P}_{3}$ & 13.90 & 0.59 & 12.07 & 21.97 & 9.42 & 2.37 \\
\hline $\mathbf{I}_{2} \mathbf{P}_{4}$ & 12.60 & 0.61 & 11.02 & 20.59 & 7.53 & 3.37 \\
\hline $\mathbf{I}_{3} \mathbf{P}_{1}$ & 21.43 & 0.52 & 7.13 & 14.00 & 20.15 & 25.39 \\
\hline $\mathbf{I}_{3} \mathbf{P}_{2}$ & 18.30 & 0.54 & 7.04 & 27.62 & 14.68 & 11.16 \\
\hline $\mathbf{I}_{\mathbf{3}} \mathbf{P}_{\mathbf{3}}$ & 13.60 & 0.61 & 19.18 & 18.27 & 6.42 & 3.30 \\
\hline $\mathbf{I}_{3} \mathbf{P}_{4}$ & 10.90 & 0.64 & 10.37 & 16.74 & 6.72 & 0 \\
\hline S.E \pm & 1.77 & 0.02 & 2.35 & 3.41 & 2.97 & 2.41 \\
\hline CDat5\% & - & - & - & - & - & - \\
\hline
\end{tabular}


Table.2 Effect of pruning severity and irrigation methods on fruit weight, fruit length, fruit breadth, fruit volume, TSS, acidity of custard apple

\begin{tabular}{|c|c|c|c|c|c|c|}
\hline $\begin{array}{l}\text { Treatment } \\
\text { details }\end{array}$ & $\begin{array}{c}\text { Fruit weight } \\
\text { (g) }\end{array}$ & $\begin{array}{l}\text { Fruit length } \\
\text { (cm) }\end{array}$ & $\begin{array}{c}\text { Fruit } \\
\text { breadth }(\mathbf{c m})\end{array}$ & $\begin{array}{c}\text { Fruit } \\
\text { volume (cc) }\end{array}$ & TSS (\%) & Acidity (\%) \\
\hline \multicolumn{7}{|c|}{ Methods of irrigation } \\
\hline$I_{1}$ & 202.17 & 6.24 & 6.45 & 135.33 & 21.42 & 0.21 \\
\hline $\mathbf{I}_{2}$ & 227.59 & 6.43 & 6.96 & 144.46 & 19.72 & 0.18 \\
\hline $\mathbf{I}_{3}$ & 233.61 & 6.51 & 7.10 & 150.50 & 19.74 & 0.19 \\
\hline S.E \pm & 5.02 & 0.063 & 0.05 & 1.96 & 0.31 & 0.001 \\
\hline CD at5\% & 19.70 & - & 0.19 & 7.67 & 1.20 & 0.004 \\
\hline \multicolumn{7}{|c|}{ Pruning intensity } \\
\hline $\mathbf{P}_{1}$ & 191.52 & 5.44 & 6.14 & 114.33 & 18.72 & 0.17 \\
\hline $\mathbf{P}_{2}$ & 221.21 & 6.40 & 6.84 & 136.89 & 19.76 & 0.18 \\
\hline $\mathbf{P}_{3}$ & 233.37 & 6.77 & 7.10 & 154.39 & 20.71 & 0.21 \\
\hline $\mathbf{P}_{4}$ & 238.49 & 6.97 & 7.27 & 168.11 & 21.98 & 0.21 \\
\hline $\mathrm{SE} \pm$ & 3.64 & 0.073 & 0.08 & 1.47 & 0.24 & 0.003 \\
\hline CD at5\% & 10.80 & 0.22 & 0.23 & 4.37 & 0.71 & 0.01 \\
\hline $\mathbf{I}_{\mathbf{1}} \mathbf{P}_{\mathbf{1}}$ & 181.68 & 5.27 & 5.74 & 107.33 & 19.94 & 0.18 \\
\hline $\mathbf{I}_{\mathbf{1}} \mathbf{P}_{2}$ & 190.99 & 6.23 & 6.57 & 127.67 & 20.91 & 0.19 \\
\hline $\mathbf{I}_{\mathbf{1}} \mathbf{P}_{3}$ & 214.35 & 6.61 & 6.63 & 143.00 & 21.76 & 0.22 \\
\hline $\mathbf{I}_{1} \mathbf{P}_{4}$ & 221.67 & 6.85 & 6.87 & 163.33 & 23.06 & 0.24 \\
\hline $\mathbf{I}_{2} \mathbf{P}_{1}$ & 198.64 & 5.48 & 6.29 & 114.83 & 18.08 & 0.16 \\
\hline $\mathbf{I}_{2} \mathbf{P}_{2}$ & 234.46 & 6.42 & 6.91 & 133.83 & 19.35 & 0.17 \\
\hline $\mathbf{I}_{2} \mathbf{P}_{3}$ & 239.14 & 6.81 & 7.18 & 159.33 & 20.01 & 0.20 \\
\hline $\mathbf{I}_{2} \mathbf{P}_{4}$ & 238.12 & 7.02 & 7.46 & 169.83 & 21.44 & 0.18 \\
\hline $\mathbf{I}_{\mathbf{3}} \mathbf{P}_{\mathbf{1}}$ & 194.24 & 5.57 & 6.40 & 120.83 & 18.13 & 0.18 \\
\hline $\mathbf{I}_{3} \mathbf{P}_{2}$ & 238.18 & 6.54 & 7.03 & 149.17 & 19.01 & 0.19 \\
\hline $\mathbf{I}_{3} \mathbf{P}_{3}$ & 246.34 & 6.89 & 7.47 & 160.83 & 20.37 & 0.20 \\
\hline $\mathbf{I}_{3} \mathbf{P}_{4}$ & 255.69 & 7.05 & 7.48 & 171.17 & 21.43 & 0.21 \\
\hline S.E \pm & 6.31 & 0.126 & 0.13 & 2.55 & 0.41 & 0.006 \\
\hline CDat5\% & - & - & - & - & - & - \\
\hline
\end{tabular}

\section{Fruit volume (cc)}

The data from Table 2 showed that, effect of pruning severity on fruit volume was found to be significant. Significantly maximum fruit volume $(168.11 \mathrm{cc})$ was produced in heavy pruning $\left(\mathrm{P}_{4}\right)$ followed by medium pruning $(154.39 \mathrm{cc})$ and light pruning $(136.89 \mathrm{cc})$. However, lowest fruit volume was recorded in control treatment $(114.33 \mathrm{cc})$. The result of present findings is in agreement with finding of Sahoo et al., (2017) in sapota. The data from Table 2 showed that, methods of irrigation on fruit volume was found to be significant. Significantly maximum fruit volume $(150.50 \mathrm{cc})$ was produced in drip irrigation $\left(\mathrm{I}_{3}\right)$ which was found at par with double furrow irrigation (144.46 cc) and lowest fruit volume was recorded in control treatment $(135.33 \mathrm{cc})$. Fruit volume in drip irrigated plant was significantly higher than the rainfed treatment in strawberry Sharma $e t$ 
al., (2005). The data presented in table 2 showed that, interaction effects due to severity of pruning and methods of irrigation was found non significant on fruit volume.

\section{TSS (\%)}

The data from Table 2 showed that, effect of pruning severity on TSS was found to be significant. The heavy pruning $\left(\mathrm{P}_{4}\right)$ produced significantly maximum TSS (21.98\%) followed by medium pruning $(20.71 \%)$ and light pruning (19.76\%). However, lowest TSS was recorded in control treatment $(18.72 \%)$. The increased rate of photosynthesis due to more light penetration into interior tree canopy increased the soluble solids in fruits of pruned trees. So as severity increases the total soluble solids increase.

These results are in accordance with those reported by Bhonsle (1972) in grape, Choudhari (2012) in custard apple and Bhagawati et al., (2015) in guava. The data from Table 2 showed that, methods of irrigation on TSS was found to be significant. Significantly maximum TSS was recorded in control treatment $(21.42 \%)$ followed by drip irrigation (19.74\%). However, minimum TSS $(19.72 \%)$ was produced in double furrow irrigation $\left(\mathrm{I}_{2}\right)$. The increased water availability leads to increase the water allocation to fruits and thereby caused dilution in the fruits. Here TSS decreases in irrigated trees as compared to non irrigated trees. These results are in agreement with findings of Chen et al., (2018) in apple. The data presented in table 2 showed that, interaction effects due to severity of pruning and methods of irrigation was found non significant on TSS.

\section{Acidity (\%)}

The data from Table 2 showed that, effect of pruning severity on acidity was found to be significant. Significantly maximum acidity $(0.21 \%)$ was produced in heavy pruning $\left(\mathrm{P}_{4}\right)$ which was at par with medium pruning $(0.21 \%)$ followed by light pruning $(0.18 \%)$. While lowest acidity was recorded in control treatment $(0.17 \%)$. The result of present findings are in arrangement with the finding of Dalal et al., (2000), Dhaliwal and Kumar (2003), Bagchi et al., (2008) in guava, Mohamed et al., (2010) in custard apple, Naseem et al., (2016) in ber. The data from Table 2 showed that, methods of irrigation on acidity was found to be significant. Significantly maximum acidity was recorded in control treatment $(0.21 \%)$ followed by drip irrigation $(0.19 \%)$ and minimum acidity $(0.18 \%)$.was produced in double furrow irrigation $\left(\mathrm{I}_{2}\right)$. Acidity was found highest in non irrigated trees and lowest in drip irrigated trees Sharma et al., (2005) in strawberry. These results are in accordance with those reported by Panigrahi et al., (2012) in mandarin. The data presented in table 2 showed that, interaction effects due to severity of pruning and methods of irrigation was found non significant on acidity.

In conclusion the fruit quality in respect of fruit weight, size, fruit size (length and breadth) and fruit volume was found highest in heavy pruning $\left(\mathrm{P}_{4}\right)$ and drip irrigation $\left(\mathrm{I}_{3}\right)$. TSS and acidity was also found maximum in heavily pruned $\left(\mathrm{P}_{4}\right)$ trees but irrigation doesn't play significant role. The medium pruning and drip irrigation produced significantly maximum 'A' graded fruits/tree. In case of custard apple the number of fruits and yield doesn't play an important role, in here ' $A$ ' grade quality fruits, fruit weight and fruit size plays the vital role and it was found that grade ' $A$ ' quality fruits was maximum in medium pruning $\left(\mathrm{P}_{3}\right)$ and drip irrigated trees $\left(\mathrm{I}_{3}\right)$, more weighted fruits fetches more price in market so farmer need more fruit in ' $\mathrm{A}$ ' grade category fruits and hence drip irrigation with medium pruning should be done. 


\section{References}

Ahmad Saeed, Chatha A.Z, Nasir Ma., Abdul Aziz, Ahmad N.V and Rehman A.K. 2006. Effect of Pruning on the Yield and Quality of Kinnow Fruit. J. Agri. Soc. Sci., 2(1), pp: 51-53.

Bagchi Torit Baran, Premasis Sukul and Bikash Ghosh, 2008. Biochemical changes during off season flowering in guava induced by pruning and bending journal of tropical agriculture, 46(1-2): 64-66.

Bhagawati Rupankar, Bhagawati Kaushik, Choudhary V.K, Rajkhowa D.P and Sharma Rupjyoti 2015. Effect of Pruning Intensities on the Performance of Fruit Plants under Mid-Hill Condition of Eastern Himalayas: Case Study on Guava. International Letters of Natural Sciences, Vol. 46, pp 46-51.

Bhanu Pratap, Singh S.K, Singh. H.K, Gaurav S.S. and Shashi Bala. 2009. Effect of pruning on physico-chemical properties of mango cv. Amrapali under high density orcharding. Annals of Horticulture. 2(1): 62-64.

Bhonsle, V.A. 1972. Pruning studies in grapes (Vitis vinifera L.). M.Sc. (Agri.) thesis, Mahatma Phule Krishi Vidyapeeth, Rahuri, Maharashtra, India.

Chen $\mathrm{Ru}$, Huang Yongye, Ji Xinglu, Xu Yehua, Xue Xiaomin, Wang Jinzheng, 2018. Effect of different irrigation methods on growth, fruit quality and yield of apple trees. Asian Agricultural Research, 10(7): 54-57.

Choudhari. S. B. 2012. Effect of time and pruning intensity on growth, yield and quality of Custard apple (Annona squamosa) Cv.Balanagar. M.Sc. (Agri.) thesis, Mahatma Phule Krishi Vidyapeeth, Rahuri, Maharashtra, India. Choudhary Kalpana and Dhakare B. B. 2018. Influence of Pruning Intensities on Growth, Yield and Fruit Attributes of
Custard Apple. Int.J.Curr.Microbiol. App.Sci. Special Issue-7: 5311-5315.

Dalal S.R., V.J. Gollivar, S.R. Patil, R.I. Gobargade and N.R. Dalai, 2000. Effect of severity of growth, yield and quality of fruits of 25 year old guava cv. Saradar J. Soils and crops 10 (20) :298300.

Dalal, S.R., V.S Ghonge and Moharai Anjalid, 2004. Standardization of pruning intensity in old guava trees cv. L-49 Ad plant Sci 17 (1): 283-286.

Dalkiliç G.G, Dalkiliç Z, Mestav H.O. 2014. Effect of Different Pruning Severity on Vegetative Growth in Peach (Prunus persica). Turkish Journal of Agricultural and Natural Sciences Special Issue: 2, pp 1505-1508.

Dhaliwal,G.S and Rawant Kumar, 2003. Effect of time and pruning intensity on the age of bearing shoot and fruit quality of Sardar guava. Haryana Journal of Horticulture Sci, 32 (1/2): 21-24.

Ehret D.L, Frey Brenda, Forge Tom, Helmer Tom and Bryla D.R. 2012. Effects of Drip Irrigation Configuration and Rate on Yield and Fruit Quality of Young Highbush Blueberry Plants. Hortscience 47(3):414-421.

Ghosh S.N. and Pal P.P. 2010. Effect of basin versus drip irrigation on quality production in Mosambi sweet orange. J. Hortl. Sci. Vol. 5 (1): 25-29.

Gupta N. and Gill M.S. 2015. Effect of intensity of pruning on yield and fruit quality of ber (Ziziphus mauritiana L.) cv. Umran International Journal of Agriculture, Environment and Biotechnology Citation: IJAEB: 8(1): 69-73.

Gurovich L A. 2002. Irrigation scheduling of table grapes under drip irrigation: an approach for saving water and energy costs in Chile. International Water and Irrigation 2: 44-50.

Hiwale, S.S. and Raturi, G.B. 1993. Effect of 
pruning severity on growth, yield and quality of ber. Progressive Horticulture 25(3-4): 161-163.

Lian Hau Ngaih , Singh Barun, Senjam B.D and Ramjan Md. 2019. Effect of Shoot Pruning on Growth and Yield of Guava (Psidium guajava L.) cv. L-49 under Foothills of Arunachal Pradesh. Int.J.Curr.Microbiol.App.Sci 8(3): 20202027.

Mohamed F. M. Shahein, Abd El- Motty, E. Z. and Fawzi M. I. F, 2010. Effect of pruning, defoliation and nitrogen fertilization on growth, fruit set and quality of Abdel-Razik Annona cultivar. Nature and Science. 8 (12) 281-287.

Meti C.B. 2013. Quality parameter of banana under drip and surface irrigation methods. Environment and Ecology 31(2A): 629-631.

Naseem Sharif, Muhammad Ishfaq, Muhammad Afzal Javaid, 2016. Effect of Different pruning times on growth and yield of ber (Zizyphus mauritiana L.), cv. Alu-bukhara.J Agric Res, vol. 54(2):251-259.

Panigrahi P, Srivastava A.K, Huchche A.D. 2012. Effects of drip irrigation regimes and basin irrigation on Nagpur mandarin agronomical and physiological performance. Agricultural Water Management 104 (2012) 79-88.

Pawar S K, Desai U T and Choudhari S M. 1994. Effect of Pruning and Thinning on Growth, Yield and Quality of Pomegranate. Annals of Arid Zone 33 (1) 45-47.
Raut, V.U. and Diware, D.V. 2005. Effect of pruning time and severity on growth and development of ber (Ziziphus mauritiana Lam.). Journal of Soils and Crops 15(1): 60-63.

Sahoo AK, Tarai RK, Dash DK, Shinde GS and Bhusan .LP. 2017. Effect of different level of pruning on growth, yield and fruit quality of sapota cv. Cricket ball under coastal zone of Odisha. International Journal of Chemical Studies 5(6): 2157-2160.

Singh Gurdarshan, 2005. Effect of different levels of nodal pruning ongrowth, flowering and fruiting of guava cv. Sardar, M.Sc. Thesis, Punjab Agriculture University, Ludhiana.

Singh Gurdarshan and Dhaliwal G.S. 2004. Effect of different pruning levels on fruit yield and quality of guava cv. Sardar. Haryana Journal of Horticultural Sciences, 33(1/2): 83-84.

Singh Rajbir and Bal J.S. 2008. Pruning in ber (Ziziphus mauritiana Lamk) - a review. Agric. Rev., 29(1): 61-67.

Sharma I P, Kumar S and Kumar P. 2005. Effect of drip irrigation and mulches on yield, quality and water-use efficiency in strawberry under mid hill conditions. Acta Horticulturae 696: 259-264.

Trevor, O. and Steven, J. M. 2009. Branch development in custard apple in relation to tip pruning and flowering including effects on production. Structure and function 23(4), pp: 855-862.

\section{How to cite this article:}

Anupama, K. C. and Panchbhai, D. M. 2020. Effect of Pruning Severity and Irrigation Methods on Quality Production of Custard Apple. Int.J.Curr.Microbiol.App.Sci. 9(12): 2272-2280. doi: https://doi.org/10.20546/ijcmas.2020.912.269 